Bull. Fac. Agric., Cairo Univ., 59 (2008):313-317.

\title{
EFFECT OF INFESTATION WITH THE LESSER (PURPLE-LINED) SUGAR-CANE STEM BORER Chilo agamemnon Bles. (LEPIDOPTERA: PYRALIDAE) ON SUGAR QUALITY AND SUGAR YIELD
}

\author{
(Received: 20.4.2008) \\ By \\ S.I. El-Sherif and H.H. Mahmoud* \\ Department of Economic Entomology and Pesticides, Faculty of Agriculture, Cairo, University, \\ Giza, Egypt and * Plant Protection Research Institute, Agricultural Research Center, Ministry \\ of Agriculture, Dokki, Giza, Egypt
}

\begin{abstract}
The relationship between three infestation parameters of cane stalks representing the different sugar-cane plantations supplied to milling factories in Middle and Upper Egypt on one hand and the standard sugar quality and sugar yield parameters applied in these factories were investigated. Infestation parameters were: infested stalks (IS\%) percentage, infested joints (IJ\%) percentage and holes/stalk (H/S) mean number. Sugar quality and sugar yield parameters correlated with these infestation parameters were: juice Brix, juice purity, Pol.\% and sugar yield. According to plantation, IS\% ranged 73-89\% with a mean of $78 \%$, IJ\% varied from $10 \%$ to $18 \%$ with a mean of $15 \%$ and $\mathrm{H} / \mathrm{S}$ ranged $3.35-5.39$ with a mean of 4.36 . On the average, $C$. agamemnon infestation decreased juice Brix, purity and Pol\% by $4.42 \%, 2.29 \%$ and $6.14 \%$, respectively. Infestation decreased sugar yield by $4.16-12.79 \%$ with a mean of $8.2 \%$. Sugar quality and yield parameters were negatively correlated to infestation parameters but none of them was significantly related to \% IS while IJ\% was significantly related to juice Brix, polarity and sugar yield \%. H/S was significantly related to juice Brix and Pol\% but insignificantly related to juice purity and \% sugar yield. Thus IJ\% seemed to be a reliable and acceptable parameter for determining the effect of $C$. agamemnon infestation on sugar quality and sugar yield. The simple regression values refer that a unit increase in IJ\% decreases the sugar yield\% by $0.04 \%$.
\end{abstract}

Key words: Chilo agamemnon, sugar quality, sugar yield.

\section{INTRODUCTION}

Egypt plants both sugar-cane (Saccharum officinarum L.) and sugar-beet (Beta vulgaris L.) crops to produce sugar. Sugar-cane is cultivated in Middle and Upper Egypt while sugar-beet plantations mostly occur in the Nile-Delta region. In Egypt, the annual area cultivated with sugar-cane exceeds 300 thousand feddans and that of sugar-beet amounts about 150 feddans. The total production of canes is approximately 15 million tons (with an average of 50 tons/ feddan) which yield above one million tons of sugar annually. Farmer's net gain is estimated at approximately \$US 210/feddan of sugar-cane and \$US 90/feddan of sugar-beet (Anonymous,2001).

In Egypt, sugar-cane plantations are subjected to infestation with a variety of serious insect pests, the most prominent of which is the "Lessers" or
"Purple-lined" stem borer, Chilo agamemnon Bles.(Lepidoptera: Pyralidae) which causes considerable damage and yield losses (El-Sherif, 1962 \& 1965; Isa, 1979 and Mahmoud, 2000).

Several authors contributed to the economic importance of $C$. agamemnon and described its infestation symptoms and type of damage to sugarcane plants (Embaby,1996 and Tohamy, 1999). In brief, the $1^{\text {st }}$ to the $3^{\text {rd }}$ larval instars feed on the unfurled central leaves of the young shoots which become decayed and turn into soft dark-brown masses thus causing the appearance of characteristic dead-hearts. Destruction of the growing points stimulates the lower buds to form tillers that give short and thin canes poor in sugar content. When attacking mature canes, the $4^{\text {th }}$ and $5^{\text {th }}$ larval instars probe into the stalks and feed on the epidermis of the internodes then bore into them ring-shaped 
semi-circular or circular tunnels filled with frass at or slightly far from the stem joints. Such griddling causes, breakage of stalks before or at harvest time. Larvae also bore pale-brown longitudinal tunnels along the whole stem. These tunnels attain a redcarmine colour as a result of secondary infection with certain bacteria.

This investigation contributes to the knowledge on correlating three infestation parameters of the cane stalks representing the different sugar-cane plantations supplied to the milling factories in Middle and Upper Egypt with the standard sugar quality and sugar yield parameters applied in these factories.

\section{MATERIALS AND METHODS \\ 2.1. Source of samples}

Egypt operates eight factories for milling sugarcane scattered along the Nile-valley. Four of those factories were selected for sampling canes and conducting chemical analyses. Selected factories are located at Abo-Qurqas (Minia Governorate, Girga (Sohag Governorate) and Nagaa-Hamadi and Dishna (Quena Governorate) 267, 502, 533 and 578 kilometers south of Cairo, respectively. Abo-Qurqas factory represented Middle Egypt while the other three factories represented Upper Egypt. All sampled canes belonged to GT.54/C-9 commercial cultivar and were taken from the harvest of plantations representing plant cane, $1^{\text {st }}, 2^{\text {nd }}, 3^{\text {rd }}$ and $4^{\text {th }}$ ratoons. Sampling canes and chemical analyses were practiced within one month about the middle of the milling season which extends from early December until late May (one factory/ week between mid-February and mid-March).

\subsection{Sampling}

As a common practice, sugar-cane growers transport harvested canes to the factories in lorries or tractor-trailed trailers. Every consignment consists of canes representing a specific plantation (e.g., plant cane, $1^{\text {st }}$ ratoon, $2^{\text {nd }}$ ratoon...etc). For every selected factory, five consignments from each of the five considered cane plantations ( plant cane, $1^{\text {st }}$ ratoon, $2^{\text {nd }}$ ratoon, $3^{\text {rd }}$ ratoon and $4^{\text {th }}$ ratoon) were randomly chosen immediately upon delivery. A random sample of 50 canes was taken from every consignment . Thus, each specific plantation at each specific factory was represented by 250 canes that were carefully inspected for $C$. agamemnon infestation then classified as infested and sound (uninfected) to work out the percentage of infested stalks (IS\%). A quantity of stalks weighing $20 \mathrm{Kg}$. was randomly taken from the separated infested canes, peeled off, washed thoroughly with water then re-examined to count the number of infested joints and holes and, hence, determine the percentage of infested joints (IJ\%) and the mean number of holes/stalk (H/S). IS\%, IJ\% and H/S were the infestation parameters used to relate infestation with $C$. agamemnon to sugar quality and sugar yield parameters. After inspection, the same quantity of infested stalks $(20 \mathrm{Kg}$.) was transferred for milling. As a check, a second quantity of stalks weighing 10 $\mathrm{Kg}$. was randomly taken from the separated sound stalks, peeled off, washed thoroughly with water then transferred for milling.

\subsection{Juice analyses}

According to the standard techniques described by Meade and Chen (1977), infested (20Kg.) and sound $(10 \mathrm{Kg}$.) stalk samples were separately milled in an electric sample pilot mill to extract row juice which was then screened and mixed thoroughly. One liter of the screened juice was taken into a glass jar of suitable size. The juice was then subjected to the standard chemical analyses commonly practiced in sugar factories to determine the following juicequality parameters: Brix (\% total solids in juice), purity and Pol\% (sucrose in juice). The extracted recovery sugar percentage. was calculated according to Hebert (1973). Data collected from the four selected factories for each of the considered infestation, sugar quality and sugar yield parameters were summed together and their means worked out for every plantation.

\subsection{Statistical analysis}

The means of infestation parameters (independent variables) were plotted against those of sugar quality and sugar yield parameters (dependent variables) then the simple correlation $(r)$ and simple regression $(b)$ coefficients for the effect of $C$. agamemnon infestation on sugar quality and sugar yield were calculated according to Steel and Torrie (1980).

\section{RESULTS AND DISCUSSION}

The means of infestation parameters as well as sugar quality and sugar yield parameters for the different sugar-cane plantations are shown in Table (1). The simple correlation and simple regression coefficients for the relationships between $C$. 
agamemnon infestation sugar quality and sugar cane and the lowest on the $3^{\text {rd }}$ ratoon. \% IJ varied yield parameters together with their significance from $10 \%$ on the $3^{\text {rd }}$ ratoon to $18 \%$ on the $2^{\text {nd }}$

Table (1):Infestation, sugar quality and sugar yield parameters for different sugar-cane plantations.

\begin{tabular}{|c|c|c|c|c|c|c|}
\hline \multirow[b]{2}{*}{ PARAMETER } & \multicolumn{5}{|c|}{ PLANTATION } & \multirow[b]{2}{*}{ MEAN } \\
\hline & $\begin{array}{l}\text { Plant } \\
\text { cane }\end{array}$ & $\begin{array}{c}\mathbf{1}^{s t} \\
\text { ratoon }\end{array}$ & $\begin{array}{c}2^{\text {nd }} \\
\text { ratoon }\end{array}$ & $\begin{array}{c}\mathbf{3}^{r d} \\
\text { ratoon }\end{array}$ & $\begin{array}{c}4^{\text {th }} \\
\text { ratoon }\end{array}$ & \\
\hline $\begin{array}{c}\text { Infestation: } \\
\% \mathrm{IS} \\
\% \mathrm{Ij} \\
\mathrm{H} / \mathrm{S}\end{array}$ & $\begin{array}{c}88.75 \\
17.36 \\
3.96 \\
\end{array}$ & $\begin{array}{c}76.25 \\
16.64 \\
5.39 \\
\end{array}$ & $\begin{array}{c}77.08 \\
18.29 \\
4.63 \\
\end{array}$ & $\begin{array}{c}73.24 \\
10.12 \\
3.53 \\
\end{array}$ & $\begin{array}{c}75.42 \\
12.92 \\
4.28 \\
\end{array}$ & $\begin{array}{c}78.15 \\
15.07 \\
4.36 \\
\end{array}$ \\
\hline $\begin{array}{l}\text { Sugar quality: } \\
\text { Juice Brix: } \\
\text { Sound canes } \\
\text { Infested canes } \\
\% \text { decrease } \\
\text { Juice purity: } \\
\text { Sound canes } \\
\text { Infested canes } \\
\% \text { decrease } \\
\text { Pol\%: } \\
\text { Sound canes } \\
\text { Infested canes } \\
\% \text { decrease }\end{array}$ & $\begin{array}{c}21.97 \\
21.16 \\
\mathbf{3 . 6 9} \\
\\
88.14 \\
80.32 \\
\mathbf{3 . 3 9} \\
\\
14.70 \\
13.72 \\
\mathbf{6 . 6 7}\end{array}$ & $\begin{array}{c}21.20 \\
19.60 \\
7.55 \\
\\
81.58 \\
79.50 \\
\mathbf{2 . 5 5} \\
\\
3.96 \\
12.58 \\
\mathbf{9 . 8 9}\end{array}$ & $\begin{array}{c}20.86 \\
19.63 \\
\mathbf{5 . 9 0} \\
\\
82.29 \\
80.97 \\
\mathbf{1 . 6 0} \\
\\
13.82 \\
12.76 \\
\mathbf{7 . 6 7}\end{array}$ & $\begin{array}{c}20.93 \\
20.74 \\
\mathbf{0 . 9 1} \\
\\
82.95 \\
81.40 \\
\mathbf{1 . 8 6} \\
\\
14.02 \\
13.66 \\
\mathbf{2 . 5 7}\end{array}$ & $\begin{array}{c}21.61 \\
20.82 \\
\mathbf{3 . 6 6} \\
\\
82.26 \\
80.00 \\
\mathbf{0 . 3 2} \\
\\
14.28 \\
13.74 \\
\mathbf{3 . 7 8}\end{array}$ & $\begin{array}{c}21.31 \\
20.39 \\
\mathbf{4 . 3 2} \\
\\
82.61 \\
80.72 \\
\mathbf{2 . 2 9} \\
\\
14.16 \\
13.29 \\
\mathbf{6 . 1 4}\end{array}$ \\
\hline $\begin{array}{c}\text { \% sugar yield: } \\
\text { Sound canes } \\
\text { Infested canes } \\
\% \text { decrease }\end{array}$ & $\begin{array}{l}12.03 \\
10.18 \\
\mathbf{1 0 . 1 4}\end{array}$ & $\begin{array}{l}11.18 \\
9.75 \\
\mathbf{1 2 . 7 9}\end{array}$ & $\begin{array}{l}11.15 \\
10.08 \\
\mathbf{9 . 6 0}\end{array}$ & $\begin{array}{c}11.41 \\
10.90 \\
\mathbf{4 . 4 7}\end{array}$ & $\begin{array}{c}11.54 \\
11.06 \\
\mathbf{4 . 1 6}\end{array}$ & $\begin{array}{c}11.46 \\
10.52 \\
\mathbf{8 . 2 0}\end{array}$ \\
\hline
\end{tabular}

Table (2): Simple correlation ( $r$ ) and simple regression (b) coefficients for the relationships between infestation parameters $(x)$ and sugar quality and sugar yield parameters $(y)$ for different sugarcane plantations.

\begin{tabular}{|c|c|c|c|c|}
\hline \multirow{2}{*}{\multicolumn{2}{|c|}{$\begin{array}{c}\text { Sugar quality and } \\
\text { sugar yield } \\
\text { parameters }(y)\end{array}$}} & \multicolumn{3}{|c|}{ Infestation parameters $(x)$} \\
\hline & & $\begin{array}{l}\text { \% IS } \\
(x 1)\end{array}$ & $\begin{array}{l}\% \mathbf{I J} \\
(x 2)\end{array}$ & $\begin{array}{l}\mathbf{H} / \mathbf{S} \\
(x 3)\end{array}$ \\
\hline \multicolumn{5}{|l|}{ Sugar quality: } \\
\hline \multirow[t]{2}{*}{ Juice Brix $(y 1)$} & $r$ & -0.07 & $-0.78 *$ & $-0.97 * *$ \\
\hline & $b$ & -0.90 & -0.07 & -0.01 \\
\hline \multirow[t]{2}{*}{ Juice purity $(y 2)$} & $r$ & -0.69 & -0.44 & -0.04 \\
\hline & $b$ & -0.13 & -0.38 & -0.93 \\
\hline \multirow[t]{2}{*}{ Pol\% (y3) } & $r$ & -0.29 & $-0.86 *$ & $-0.86^{*}$ \\
\hline & $b$ & -0.58 & -0.03 & -0.03 \\
\hline \multirow[t]{2}{*}{ Sugar yield $(y 4)$} & $r$ & -0.43 & $-0.83 *$ & -0.73 \\
\hline & $b$ & -0.39 & -0.04 & -0.10 \\
\hline
\end{tabular}

levels are presented in Table (2). Data in Tables(1\&2) emphasize the pronounced pest effect on sugar-cane plantations. \%IS ranged $73-89$, with a mean of $78 \%$. The highest \% IS occurred on plant ratoon, with a mean of $15 \%$. The mean number of holes / stalk $(\mathrm{H} / \mathrm{S})$ reached a maximum of 5.39 on the $1^{\text {st }}$ ratoon and a minimum of 3.53 on the $3^{\text {rd }}$ ratoon, with a mean of 4.36. Discrepancy of the arrangement order of the different sugar-cane plantations according to infestation parameters made comparison between them, with respect to infestation susceptibility with $C$. agamemnon, more or less difficult. However, the simple correlation and simple regression coefficients for the relationship between infestation parameters and sugar yield were negatively insignificant for both $\%$ IS and $\mathrm{H} / \mathrm{S}$ but significantly negative at 0.05 level for $\%$ IJ. Thus, based on $\%$ IJ values, the $2^{\text {nd }}$ ratoon and plant-cane plantations were the most susceptible $\left(18.3 \% \& 17.4 \%\right.$, respectively) while the $1^{\text {st }}$ ratoon plantations were slightly less susceptible (16.6\%) and both the $4^{\text {th }}$ and the $3^{\text {rd }}$ ratoons were the least susceptible $(12.9 \% \& 10.1 \%$, respectively).

As seen in Table (1), the different sugar quality values parameters and the percentages of decrease in them differed from one plantation to another. Juice Brix ranged $19.60-21.16$, with a mean of 
20.39 for infested canes and 20.86-21.97, with a mean of 21.31 for sound canes. Juice purity varied from 79.50 to 81.40 , with a mean of 80.72 for infested canes compared to 81.58 - 88.14 , with a mean of 82.61 for sound canes. Pol\% range was 12.58 - 13.74, with a mean of 13.29 for infested canes and 13.82 - 14.70, with a mean of 14.16 for sound ones. These values indicate that $C$. agamemnon infestation decreased juice Brix, purity and $\mathrm{Pol} \%$ by an average of $4.32 \%, 2.29 \%$ and $6.14 \%$, respectively. Infestation further affected the $\%$ sugar yield which ranged $11.15-12.03 \%$, with a mean of $11.46 \%$ and dropped to $9.75-11.06 \%$, with a mean of $10.52 \%$ for sound and infested canes thus decreasing sugar yield by $4.16-12.79 \%$, with a mean of $8.20 \%$ according to plantation.

Table (2) refers that, generally speaking, sugar quality and yield parameters were negatively correlated to the three considered infestation parameters. However, none of the former parameters was significantly correlated to \%IS. Correlation coefficients for the relationship between IJ\%on one hand and juice Brix, \% polarity and \% sugar yield on the other were statistically significant. The number of holes/stalk $(\mathrm{H} / \mathrm{S})$ was highly significantly related to juice Brix, significantly related to Pol\% but insignificantly related to either juice purity or \%sugar yield. These results suggest that IS\% seems to be an unacceptable parameter for determining the effect of $C$. agamemnon infestation on sugar yield. Meanwhile, IJ\% proved to be a reliable and significant parameter for the same purpose. $\mathrm{H} / \mathrm{S}$ is a more or less debatable parameter for determining the effect of infestation on sugar yield as it significantly or highly significantly affected some of the juice parameters but its influence on \% sugar yield was insignificant. According to regression values, an average increase of $1 \%$ in IJ\% decreases the $\%$ sugar yield by $0.04 \%$.

The above results seem to coincide with the findings of the previous investigators in Egypt. Kira and El-Sherif (1973) estimated that an increase of $1 \%$ dead tops reflects a loss of $0.65-0.67 \%$ in sugar yield. Khedr (1981) claimed that the average loss in sugar yield due to $C$. agamemnon infestation is 15.16\%. Embaby (1996) found that a mean of $13.42 \%$ infested joints caused $3.55 \%$ loss in sugar yield. He added that joint infestation reflected obvious decreases in juice Pol\% (sucrose \% in juice) and purity and increased reduced sugars and fibers.
Tohamy (1999) generalized that an increase of infestation with $C$. agamemnon reduces the weight of canes, juice Brix and sucrose. In contradiction with the above-mentioned findings Abu-Dooh (1980) and Soliman et al. (1987) reported insignificant relationships between the percentage of bored joints, percentage of infested canes or the number of larvae on one hand and the milled juice Brix, sucrose, glucose or total soluble solids"T.S.S."values on the other hand. Similar studies on other species of Chilo ( C.infuscatellus, C. tumidicostalis and C.auricilius) in India and Taiwan revealed that sugar recovery percentage was higher in uninfested than infested canes and that infestation reduced juice Brix, Pol of sucrose and glucose as well as commercial cane sugar "C.C.S"(Chang \&Wang,1995; Gupta \& Singh, 1997 and Maninder-Shenhmar el al., 1998).

\section{REFERENCES}

Abu-Dooh A.M. (1980). Varietal resistance of certain sugar-cane varieties infestation by sugar-cane borers. M.Sc. Thesis, Fac. of Agric., Assiut Univ., Egypt, 101pp.

Annonymous (2001). Sugar crops and sugar production in Egypt. Annual report on sugar crops, Sugar Crops Council, Ministry of Agriculture, Egypt, 297 pp.

Chang Y. S. and Wang K. R. (1995). Statistical analysis of the effect of sugar-cane borer damage on cane juice quality. Report of the Taiwan Sugar Research Institute,(149):1-12.

El-Sherif S.I. (1962). Studies on the corn borers in Alexandria district, Egypt, Chilo suppressalis Wlk. (Lepidoptera, Crambidae), Pyrausta nubilalis Hbn.(Lepidoptera: Pyraustidae) and Sesamia cretica Led. (Lepidoptera: Agrotidae). M.Sc. Thesis, Fac. of Agric., Alexandria Univ., Egypt,199pp.

El-Sherif S.I. (1965). Studies on the corn borers in the Alexandria district. Ph.D. Thesis, Fac. of Agric., Alexandria Univ., Egypt, 362pp.

Embaby M.M. (1996). Ecological and biological approaches in an attempt to face the problem of the purple lined borer, Chilo agamemnon Blesz. in sugar-cane production areas of Egypt. Ph.D. Thesis, Fac. of Agric., El-Minia Univ., Egypt, 176pp.

Gupta M.K. and Singh S.N. (1997). Quantitative loss in sugar-cane by plassey and top borer damage. Indian Sugar, 47(4):275-277. 
Hebert L.P. (1973). Testing of sugar-cane varieties for milling quality. Sugar J., 36 (4): 8-12.

Isa A.L. (1979). Management of pests of certain field crops in Egypt. Proc. Int. Conf. Env. Haz. Agrochem. Vol. II: 1084-1090.

Khedr G.E. (1981). Certain ecological studies on sugar-cane borers in Upper Egypt. Ph.D. Thesis, Fac. of Agric, Al-Azhar Univ., Egypt, $125 \mathrm{pp}$.

Kira M.T. and El-Sherif H.(1973). Estimation of losses in cane and sugar yields caused by Chilo agamemnon Blesz. infestation. Bull. Soc. Ent. Egypt -271-

277.

Mahmoud H.H.(2000). Ecological and control studies on the lesser sugar-cane borer, Chilo agamemnon Bles. (Lepidoptera: Pyralidae) in sugar-cane fields. M.Sc. Thesis, Fac. of Agric., Cairo Univ., Egypt, 75pp.

Maninder-Shenhmar V., Duhra G.C., Doomra M.S. and Shenhmar M. (1998). Assessment of losses caused by Chilo auricilius Dudgeon (Lepidoptera: Crambidae). Indian Sugar,48 (1):39-41(c.f. Mahmoud,2000).

Meade G.P. and Chen J.C.P. (1977). Meade-Chen Sugar Handbook, $10^{\text {th }}$ edition, John Wiley and Sons Inc.,New York, 75pp.(c.f. Embaby, 1996).

Soliman M.A., Moftah E.A., Younis A.M. and Mohamed K.K. (1987). Factors affecting the susceptibility of sugar-cane varieties to borer infestation. Minia J. Agric. Res. \& Dev., 9 (3):1349-1361.

Steel R.G.D. and Torrie J.H. (1980). Principles and procedures of statistics, a biometrical approach. $2^{\text {nd }}$ edition, McGraw-Hill Book, Co., N.Y.USA.

Tohamy T.H. (1999). Ecological studies on certain sugar-cane pests in Middle Egypt. Ph.D. Thesis, Fac. of Agric., El-Minia Univ., Egypt, 200 pp.

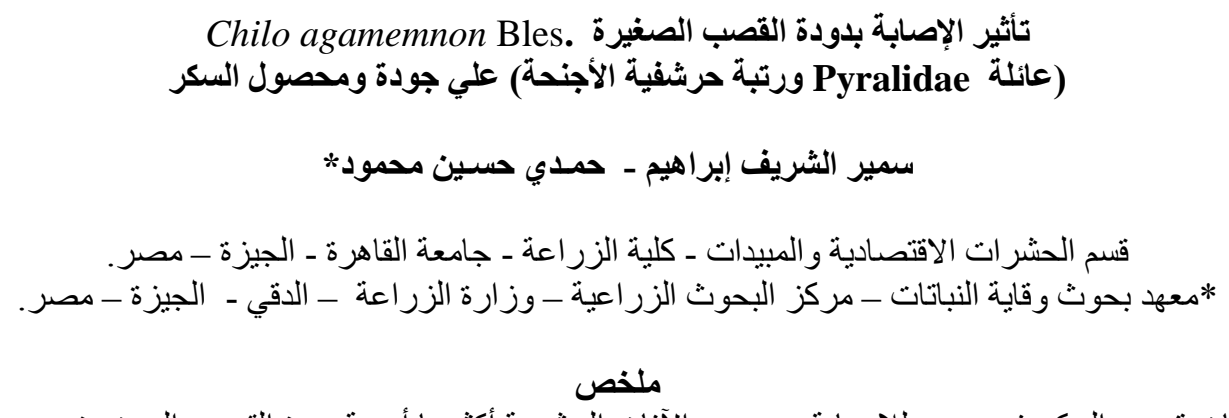

تلتعرض زر اعات قصب السكر في مصر للإصابة بعديد من الآفات الحشرية أكثرها أهمية دودة القصب الصغيرة

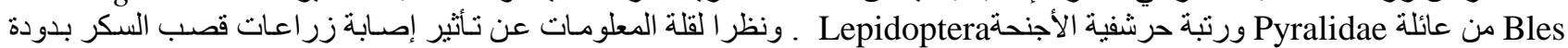

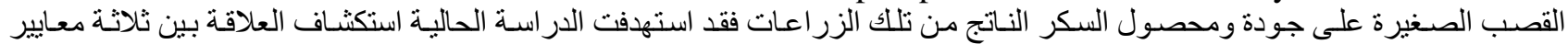

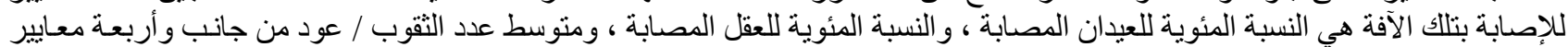

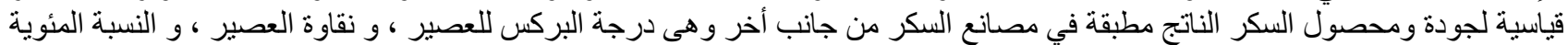

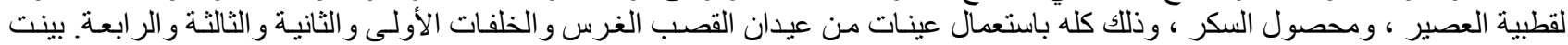

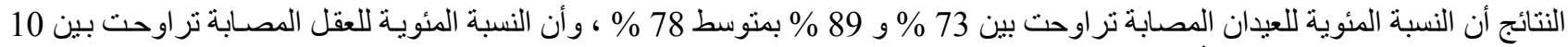

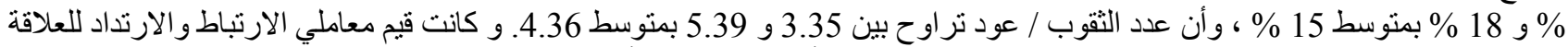

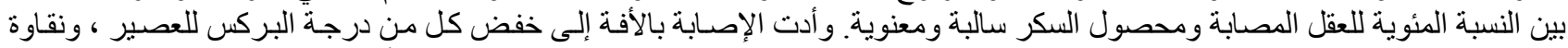

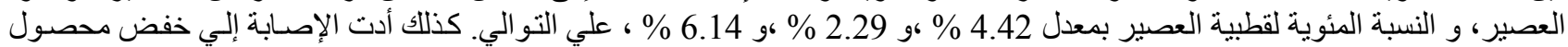

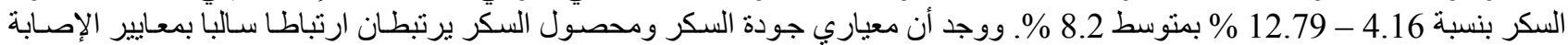

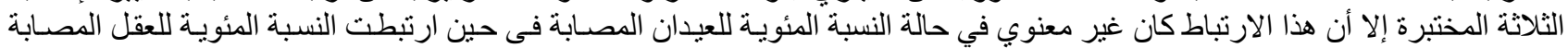

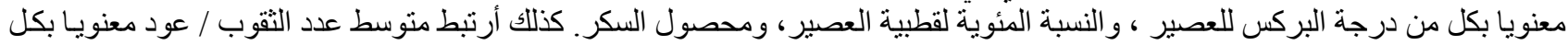

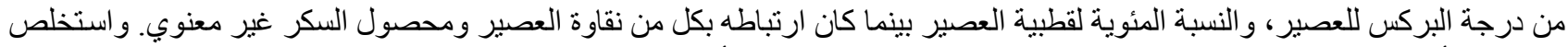

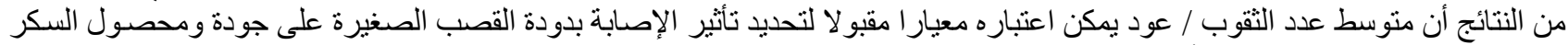

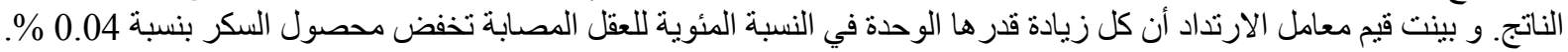

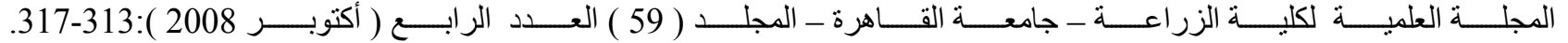



